\title{
A Qualitative Study on Emergency Health Care Worker (EHCW) Perception towards COVID-ACLS Simulation Training in Resuscitating Suspected COVID-19 Patients
}

(Suatu Kajian Kualitatif terhadap Persepsi Pekerja Kesihatan Kecemasan (EHCW) terhadap Latihan Simulasi COVIDACLS dalam Resusitasi Pesakit Disyaki COVID-19)

\author{
Jebby Yit, Alias Mahmud*, AZlan Helmy Abd Samat, DaZlin Masdiana Sabardin, Mohd Hisham Mohd \\ ISA, ISMAIL MOHD SAIBOON \& MOHD JOHAR JAAFAR
}

\begin{abstract}
The emergence of COVID-19 pandemic has caused difficulty to emergency-HCW (EHCW) in resuscitating high-risk patients. We set out to explore EHCW's perception after undergoing COVID-ACLS resuscitation training and address their anxiety of working in this pandemic. A qualitative case study using focused group discussion was conducted among EHCW who have undergone COVID-ACLS training. Five semi-structured questions exploring respondent's confidence level, anxiety factors, areas of improvement for COVID-ACLS and if this COVID-ACLS training is sufficient. Inductive and deductive thematic analysis approach was done to analyse the result. $20 \mathrm{EHCW}$ participated in this study. Out of 4 themes, 11 subthemes were identified based on the respondents. They were acquired new knowledge, self-precaution, method of delivery, concerns of self and family members, stigmatisation, insufficient protective methods, underappreciation, regular training sessions, other modalities for learning, course duration; and unsatisfactory reading material. New knowledge and self-precaution were noted to be an important aspect that boosts confidence among EHCW. The main factor that increased anxiety was safety issues and disease spreading to family members, colleagues, and society. In conclusion, COVID-ACLS training is able to boost EHCW confidence in resuscitating high-risk patients. Factors leading to anxiety among EHCW should also be addressed during this pandemic to ensure psychological welfare and mental health are not affected. Regular training and utilisation of other teaching modalities such as video are perceived as a helpful adjunct in boosting their confidence. The utilisation of new training approach should be explored in enhancing EHCW's knowledge and confidence.
\end{abstract}

Keywords: Anxiety; COVID-19; emergency; health care worker; resuscitation

\section{ABSTRAK}

Pandemik COVID-19 telah menyebabkan kesusahan kepada anggota kecemasan-HCW (EHCW) dalam melaksanakan resusitasi pesakit berisiko tinggi. Tujuan kajian ini adalah untuk mengkaji pandangan EHCW yang telah menjalani latihan COVID-ACLS serta menangani kerisauan semasa bertugas dalam pandemik ini. Kajian kualitatif ini menggunakan sesi temu bual berfokus dengan lima soalan semi-struktur bagi melihat tahap keyakinan responden, faktor kegelisahan, cara penambahbaikan COVID-ACLS dan untuk mengetahui adakah latihan COVID-ACLS ini mencukupi. Sesi temu bual dianalisis dan ditafsir menggunakan tematik analisis secara induktif dan deduktif. 20 anggota EHCW telah menyertai kajian ini. Dalam keempat-empat tema ini, 11 subtema telah ditemui. Antaranya ialah pembelajaran ilmu baru, kaedah untuk melindungi diri, keselamatan diri dan keluarga, stigma, kekurangan sumber pelindungan, rasa kurang dihargai, sesi latihan yang lebih kerap, modaliti lain untuk pembelajaran, jangka masa latihan dan bahan bacaan yang kurang memuaskan. Pembelajaran ilmu baru dan kaedah melindungi diri merupakan aspek penting dalam menjana keyakinan EHCW. Faktor utama yang meningkatkan kerisauan adalah isu keselamatan dan penyakit boleh menjangkiti kepada ahli keluarga, rakan sekerja dan masyarakat. Kesimpulannya, COVID-ACLS berkemampuan untuk meningkatkan 
keyakinan EHCW untuk melaksanakan resusitasi pesakit berisiko tinggi. Faktor yang menyumbang kepada kerisauan EHCW perlu diberi perhatian semasa pendemik ini supaya kesejahteraan psikologi dan kesihatan mental mereka dapat dijaga. Latihan yang kerap dan penggunaan modaliti pengajaran seperti video juga boleh membantu untuk meningkatkan keyakinan EHCW. Penggunaan latihan kaedah lain perlu diterokai untuk menambah ilmu pengetahuan dan keyakinan EHCW.

Kata kunci: COVID-19; kecemasan; kegelisahan; pekerja kesihatan; resusitasi

\section{INTRODUCTION}

On $11^{\text {th }}$ March 2020, the World Health Organization (WHO) has declared COVID-19 as a worldwide pandemic. This initially started with an incident reported in Wuhan, China, whereby 44 patients diagnosed with pneumonia of unknown aetiology. Later, more than 70,000 cases are reported two months after initiation of cases, among which 1,716 cases have been confirmed among health care workers (HCW) (Wu et al. 2020). Within four months, more than $3,300 \mathrm{HCW}$ are diagnosed to have coronavirus infection in China ( $4 \%$ of the total reported infections). The National Hospital Infection Management and Quality Control Centre in China has concluded that one of the reasons for the high number of infected HCW during emergency outbreak is due to inadequate training for infection prevention and control for respiratory-borne infectious diseases (Wu \& Mcgoogan 2020).

Malaysia, on the other hand, has reported to have $1880 \mathrm{HCW}$ who have tested positive for COVID-19. Till today, the numbers of coronavirus patients grow daily, as well as the HCW that care for them (Ministry of Health Malaysia 2020). Due to this reason, we have introduced a COVID-ACLS training module as part of preparing our emergency health care worker (EHCW), which are $\mathrm{HCW}$ working in ED. This training module was developed by a team of emergency physicians with reference to the American Heart Association (AHA) and WHO guidelines. A simulation-based training approach was used to deliver the module. Pre-reading material on the COVID-19 mode of spread, aerosol-generating procedure (AGP), risk of infections and step-by-step on how to perform airway management and resuscitation was also provided for EHCWs.

The COVID-19 outbreak has overwhelmed the health care system. HCW, especially the frontliners have experienced tremendous pressure in attending a high workload and also exposing themselves to COVID-19 patients. Abd Samad et al. (2020) and Li et al. (2020) stated that HCW involved in treating COVID-19 patients also suffer from vicarious traumatisation from non-medical personnel due to potentially having a higher risk of being infected. Other concerns such as lacking knowledge about COVID-19, higher education attainment, infecting family or friends are contributing factors to $\mathrm{HCW}$ to develop anxiety ( $\mathrm{Du}$ et al. 2020). Hence it is vital to address anxiety among HCW so psychosocial support could be provided to increase their resilience. This study will be used to explore EHCW's perception regarding simulation training in a subjective manner and also to address EHCW concerns in resuscitating a potential COVID-19 patient. It is important to address their anxiety of working in a COVID-19 setting so that their psychological welfare and mental health would not be affected.

\section{MATERIALS AND METHODS}

We conducted an exploratory qualitative case study to inquire about the perception of health care workers regarding COVID-ACLS simulated training in resuscitating a suspected COVID-19 patient and their anxiety factors during the pandemic. Qualitative research has been chosen because it is an interactive and naturalistic inquiry approach that emphasises the description of given meanings about human experiences and realities (Denzin \& Lincoln 2008; Lincoln 2007). Therefore, employing an exploratory qualitative design in this study is appropriate to capture the subjective and humanistic perspective of work from emergency health care workers during the COVID-19 pandemic.

The study was conducted in the emergency department of a teaching university hospital in Kuala Lumpur, Malaysia. This hospital provides 24-hour emergency services and accepts COVID-19 positive patients for in-patient health care. The population for this study were the emergency department health care workers 
which include doctors, staff nurses and assistant medical officer from a single centre - Hospital Canselor Tuanku Muhriz (HTCM) that have consented for the study and fulfilled the inclusion and exclusion criteria.

This study commenced after obtained formal approval from the Research and Ethics Committee of PPUKM (JEP-2020-481). Participants were ensured anonymity and confidentiality. The data collected from the interview were kept confidentially and only accessible to the research team members. This study's purpose and interview type were fully explained to the participants. Informed written consents were given to the participants to ensure their right to full disclosure.

We have adopted purposeful sampling for this study. According to Patton (2002), purposeful sampling enabled the researcher to be able to study informationrich cases. These cases then enabled us to yield insight and in-depth understanding rather than an empirical generalisation from a random sampling approach. Our study samples involved $20 \mathrm{HCW}$ who have undergone COVID-ACLS training.

The study data was collected via a face-to-face focus group interview (FGI) on all selected participants. Each FGI has included 5 participants consisting of medical officers, assistant medical officers and staff nurses. The interview took approximately 30-45 minutes for each session. An interview protocol has been used as a guide for researches during interviews. All participants were invited to freely express their perceptions, concerns and suggestions regarding COVID-ACLS simulation training. We have used a voice recorder during the interviews for audiotape purpose to obtain accurate conversational data for transcription and analysis later. Ipad pro-2020 was used to record interviews.

TABLE 1. Question asked in the semi-structured interviews

\begin{tabular}{|c|c|}
\hline No & Questions \\
\hline 1. & $\begin{array}{l}\text { Does this training enhance your confidence in handling COVID-19 cases? } \\
\text { Probe: What aspect - knowledge, skills? }\end{array}$ \\
\hline 2. & $\begin{array}{l}\text { Does this training reduce your anxiety in handling COVID-19 cases? } \\
\text { Probe: What aspect of your fear and anxiety and how this training can reduce it? }\end{array}$ \\
\hline 3. & $\begin{array}{l}\text { How to improve the COVID-ACLS simulation training and what are the areas? } \\
\text { Probe: What would you suggest for future simulation training? }\end{array}$ \\
\hline 4. & $\begin{array}{l}\text { What makes you better after attending COVID-ACLS training? } \\
\text { Probe: Why do you say that? }\end{array}$ \\
\hline 5. & $\begin{array}{l}\text { How the guidelines of this training can help you in handling COVID-19 cases? } \\
\text { Probe: Are these guidelines clear, easy to understand and how to improve them so it can be used } \\
\text { more easily by all health care workers? }\end{array}$ \\
\hline 6. & $\begin{array}{l}\text { What is your future plan to improve your knowledge and skills in handling COVID-19 cases? } \\
\text { Probe: What areas of improvement and how to get it? }\end{array}$ \\
\hline
\end{tabular}

DATA ANALYSIS

Each interview was recorded and then transcribed verbatim in English by the researcher. Significant observations from the participant's physical expressions and gestures based on field notes recorded during interviews were also incorporated. Interviews were analysed using a thematic coding approach as suggested by Merriam and Tisdell (2015). The analysis process has 
been done with caution, and researchers have compared each interview through triangulation of data. Consistent themes (saturation point) were then obtained and in line with the objectives of the study. Three basic steps were involved in conducting content analysis, which are: identifying meaning units, creating categories and developing themes of categorisation (Berg 2007). The analysis process was accelerated using the NVivo 12 software.

The transcription of 20 participants were read repeatedly to reinforce further understanding of the contextual meaning. The content of transcription and result has been validated by 2 specialists. Texts with the same central meaning were segmented to meaning units and sorted out from transcriptions. Codes were then assigned to the meaning units to represent threads from the dimension of EHCWs. Meaning units sharing the same manifested threads and contents will be divided into subthemes. Accumulation and comparison of subthemes are performed by the researcher to explore similarities and differences in the participants' dimensions. Subsequently, analogue subthemes are sorted together into themes. The entire text was examined, and each meaning unit was categorised appropriately by the researcher according to the content and contextual meaning.

\section{RESULTS}

In our study, we enrolled 13 females and 7 males between 31 and 45 years old. Our sample consisted of 10 medical officers, 6 assistant medical officers and 4 nurses recruited from the emergency department of PPUKM who have undergone the COVID-ACLS training. Their working experience ranged from 6 to 20 years in emergency medicine. Sixteen of the participants were married, whereas the remaining 4 are still single. The demographic characteristics of the participants are summarised in Table 2.

TABLE 2. Demographic characteristic of emergency health care workers $(\mathrm{N}=20)$

\begin{tabular}{lc}
\hline & Participated health care workers N (\%) \\
\hline Age (years) & $15(75)$ \\
$31-35$ & $4(20)$ \\
$36-40$ & $1(0.05)$ \\
$41-45$ & \\
Gender & \\
Female & $13(65)$ \\
Male & $7(35)$ \\
& \\
Ranking & \\
Staff nurse & \\
Medical assistant & $4(20)$ \\
Medical officer & $6(30)$ \\
Years of working experience (years) & $10(50)$ \\
6-10 & \\
11-15 & \\
16-20 & $14(70)$ \\
Marital status & $3(15)$ \\
Married & $3(15)$ \\
Single & \\
\hline
\end{tabular}


Analysis of the transcripts for these focus groups interviews was done according to the four main themes: confidence level, anxiety of EHCW, area for improvement for COVID-ACLS and sufficiency of COVID-ACLS course. The subthemes emerging from each theme are listed in Table 3 .

TABLE 3. Themes and subthemes emerging from the interview data

\begin{tabular}{|c|c|c|c|}
\hline & Subtheme & Code & Quotations \\
\hline & $\begin{array}{l}\text { Acquired new } \\
\text { knowledge }\end{array}$ & $\begin{array}{c}\text { Aerosolised generating } \\
\text { procedure, personal } \\
\text { protective equipment, } \\
\text { proper way/guideline, } \\
\text { eye-opening, make a } \\
\text { difference }\end{array}$ & $\begin{array}{l}\text { "I feel more confident to handle aerosolised generating procedure" }\left(\mathrm{G}_{5} \mathrm{P}_{15}\right) \\
\text { "As a hospital staff, we really need the protection especially wearing personal } \\
\text { protective equipment. So, we really need to heighten up precaution about } \\
\text { it" }\left(\mathrm{G}_{4} \mathrm{P}_{12}\right) \\
\text { "As long as we have the proper guideline and adhere to it, then yes I am } \\
\text { more confident" }\left(\mathrm{G}_{4} \mathrm{P}_{11}\right) \\
\text { "This training actually opens my eyes on how important it is to be safe } \\
\text { especially in the proper way of wearing PPEs, your tyvex and with me } \\
\text { practising all those" }\left(\mathrm{G}_{1} \mathrm{P}_{2}\right) \\
\text { "I have worked in resus before attending the training and also after attending } \\
\text { the training, it does make a difference... after I went through the training, } \\
\text { at least you have some steps in your mind of what to do first, what is the } \\
\text { priority and prioritise it first" }\left(\mathrm{G}_{2} \mathrm{P}_{6}\right)\end{array}$ \\
\hline
\end{tabular}

ii. Self-precaution

iii. Method of delivery
Protect, own safety, contract illness, heighten up precaution, minimise contact to AGP

Simulation, relate to daily resuscitation, assigned roles, hands-on
"So we know what to do, we know how to protect ourselves and we know how to protect our staffs. That's why I think it's good" $\left(\mathrm{G}_{6} \mathrm{P}_{19}\right)$

"There is no emergency in pandemic, it's just that they wanted to tell us that we also have to think about our own safety as well" $\left(\mathrm{G}_{1} \mathrm{P}_{4}\right)$

"We need to protect ourselves and at the same time saving patient's lives. If there is no guideline, we will be exposing ourselves to contract the illness, which is endangering ourselves" $\left(\mathrm{G}_{4} \mathrm{P}_{11}\right)$

"As a hospital staff, we really need the protection especially wearing PPE. So, we really need to heighten up precaution about it" $\left(\mathrm{G}_{4} \mathrm{P}_{12}\right)$

"...limiting the staffs to be near patient during intubation to only 2 people because they want to minimise the staff contact to AGP" $\left(\mathrm{G}_{5} \mathrm{P}_{15}\right)$

"They simulated the true resuscitation team, so one team consisting of medical officer, medical assistant, staff nurse. They gave us task to resuscitate the mannequin and intubate the mannequin. Then everybody experiences the role and can relate it to our daily resuscitation in red zone" $\left(\mathrm{G}_{3} \mathrm{P}_{8}\right)$

"The training also assigned role to us like team leader, team mate 1 , team mate 2 etc. From there we can separate our roles to do each different assignment, which is very organised" $\left(\mathrm{G}_{4} \mathrm{P}_{10}\right)$

"When we undergo hands-on training, we learned about how to reduce the risk of COVID transmission" $\left(\mathrm{G}_{6} \mathrm{P}_{18}\right)$ 
Theme II: Anxiety of EHCW in a susceptible to COVID-19 environment

\begin{tabular}{|c|c|c|c|}
\hline & Subtheme & Code & Example quotations \\
\hline i. & $\begin{array}{l}\text { Concerns on } \\
\text { self and family } \\
\text { members }\end{array}$ & $\begin{array}{l}\text { Worried, scared, my } \\
\text { family kids, wife, } \\
\text { children }\end{array}$ & $\begin{array}{l}\text { "I'm worried that I will be the spreader...I'm scared that I would bring the } \\
\text { virus back to my family" }\left(\mathrm{G}_{5} \mathrm{P}_{14}\right) \\
\text { "My anxiety is, because I have kids, wife which is not front liners. So, every } \\
\text { time when I go back home, I'm always worried if I'm positive or not? What } \\
\text { if I bring to my kids and all?" }\left(\mathrm{G}_{1} \mathrm{P}_{3}\right) \\
\text { "I will keep thinking if it is safe for me to go work? How about later when } \\
\text { I come back from work? Because my children are still young" }\left(\mathrm{G}_{6} \mathrm{P}_{17}\right)\end{array}$ \\
\hline ii. & Stigmatisation & $\begin{array}{l}\text { Look down, guilty, } \\
\text { stigmata, blaming }\end{array}$ & $\begin{array}{l}\text { "Whoever that gets COVID at the first time, there will be somebody who } \\
\text { will look down, as if that person is guilty" }\left(\mathrm{G}_{2} \mathrm{P}_{5}\right) \\
\text { "Our colleague was told to be positive. Again, stigmata wise it affected her } \\
\text { badly...I observed on the floor, when one of us actually contract it and it } \\
\text { starts to be a blaming game, 'did you wear this? Did you do this?' instead } \\
\text { of being more supportive... }\left(\mathrm{G}_{2} \mathrm{P}_{7}\right)\end{array}$ \\
\hline iii. & $\begin{array}{l}\text { Insufficient } \\
\text { protective } \\
\text { equipment }\end{array}$ & $\begin{array}{l}\text { Insufficient, not enough, } \\
\text { gone off, depleted, } \\
\text { LUCAS, PAPR }\end{array}$ & $\begin{array}{l}\text { "When there is PPE insufficiency, now we have to force our worker to } \\
\text { come to work with the impression of not protected or not optimising their } \\
\text { PPEs" }\left(\mathrm{G}_{1} \mathrm{P}_{4}\right) \\
\text { "...I think within one month our PPE should have just gone off...finally } \\
\text { when it reaches the end when our PPE is almost depleted then only we get } \\
\text { very anxious and finding PPE everywhere..." }\left(\mathrm{G}_{1} \mathrm{P}_{4}\right) \\
\text { "You know this will last for a few more years, so buck up on PPEs ..." }\left(\mathrm{G}_{2} \mathrm{P}_{5}\right) \\
\text { "...one way of improvement is also to recommend LUCAS usage [during } \\
\text { CPR]" }\left(\mathrm{G}_{6} \mathrm{P}_{20}\right) \\
\text { "our current PPE is not that complete as compared to what China team had. } \\
\text { So, maybe we need to put something like PAPR in those who are intubating } \\
\text { patient" }\left(\mathrm{G}_{3} \mathrm{P}_{9}\right)\end{array}$ \\
\hline iv. & Underappreciation & $\begin{array}{l}\text { No appreciation, being } \\
\text { used, human shield, } \\
\text { incentive, allowance, } \\
\text { extra holidays }\end{array}$ & $\begin{array}{l}\text { "You are overworking your front liners and obviously the appreciation is } \\
\text { not there" }\left(\mathrm{G}_{2} \mathrm{P}_{7}\right) \\
\text { "I feel like we are being used like a human shield because we are front liners } \\
\text { of the front liners" }\left(\mathrm{G}_{6} \mathrm{P}_{19}\right) \\
\text { "... maybe they can provide incentives for us like for example extra holidays, } \\
\text { allowances" }\left(\mathrm{G}_{6} \mathrm{P}_{20}\right)\end{array}$ \\
\hline
\end{tabular}

Theme III: Area for improvement

\begin{tabular}{|c|c|c|c|}
\hline & Subtheme & Code & Example quotations \\
\hline i. & $\begin{array}{l}\text { Regular training } \\
\text { sessions }\end{array}$ & $\begin{array}{l}\text { More frequent, repeat } \\
\text { of trainings, regularly, } \\
\text { twice a year }\end{array}$ & $\begin{array}{l}\text { "Because it was done once only, so I think it should be done more } \\
\text { frequently...multiple times, so we can refresh back" }\left(\mathrm{G}_{6} \mathrm{P}_{19}\right) \\
\text { "I think the training should be more frequent" }\left(\mathrm{G}_{1} \mathrm{P}_{2}\right) \\
\text { "...I actually feel that it's supposed to repeat every monthly or } 2 \text { monthly } \\
\text { so that people will feel fresh" }\left(\mathrm{G}_{2} \mathrm{P}_{6}\right) \\
\text { "If this COVID period is prolonged, I would like to suggest we have the } \\
\text { training at least twice a year" }\left(\mathrm{G}_{5} \mathrm{P}_{16}\right)\end{array}$ \\
\hline
\end{tabular}


ii. Other modalities for learning
Teaching video, visual demonstration
"It is better to have a teaching video that summarised our training and guideline so we can replay it repeatedly to refresh our memory" $\left(\mathrm{G}_{4} \mathrm{P}_{11}\right)$ "If they provide a teaching video and reading material, then we go through the hands-on training it will be better" $\left(\mathrm{G}_{5} \mathrm{P}_{14}\right)$

"If we are just reading through the guidelines, we might miss some important points. But if adding on with visual demonstration, it will be easier for us to pick out some abnormality and we can clear our doubts straight one the spot" $\left(\mathrm{G}_{5} \mathrm{P}_{16}\right)$

"If we had a teaching video it will be easier for us to comprehend. So we won't miss any steps, just follow what's showed on the video" $\left(\mathrm{G}_{6} \mathrm{P}_{18}\right)$

\begin{tabular}{|c|c|c|c|}
\hline & Subtheme & Code & Example quotations \\
\hline & Course duration & $\begin{array}{l}\text { short, multiple times, } \\
\text { time constraint, } \\
\text { not adequate, } \\
\text { compartmentalise }\end{array}$ & $\begin{array}{l}\text { "The course is short so not many people can try the hands on...like certain } \\
\text { people can only observe and can't get the points. I think it should be done } \\
\text { multiple times" }\left(\mathrm{G}_{6} \mathrm{P}_{19}\right) \\
\text { "During the training prior to this, I think it was five of us in a group with } \\
\text { time constraint of } 2-2.5 \text { hours, that is not adequate. I think it should be } \\
\text { longer and everyone should participate in different role plays" }\left(\mathrm{G}_{1} \mathrm{P}_{3}\right) \\
\text { "I think we should compartmentalise into stations where we can learn how } \\
\text { to don properly and breech check properly as one station" }\left(\mathrm{G}_{2} \mathrm{P}_{5}\right)\end{array}$ \\
\hline ii. & $\begin{array}{l}\text { Unsatisfactory } \\
\text { reading material }\end{array}$ & $\begin{array}{l}\text { Too simple and } \\
\text { short, too simplified, } \\
\text { no explanation, not } \\
\text { properly outlined, }\end{array}$ & $\begin{array}{l}\text { "It was too simple and short. This is a new guideline but it was too } \\
\text { simplified and we need to learn new things. So when it was written to be } \\
\text { so short and simple, we couldn't really imagine until we go through the } \\
\text { training steps by steps then only we understand fully" }\left(\mathrm{G}_{6} \mathrm{P}_{20}\right) \\
\text { "When you read it is quite simple actually, but to understand it better what } \\
\text { is the reason behind...for example you want to intubate in the position with } \\
\text { the acrylic box, why such thing? It is because to prevent AGP. But those } \\
\text { AGP is not mentioned in the reading material. }\left(\mathrm{G}_{1} \mathrm{P}_{1}\right) \\
\text { "There is no explanation to the reason behind certain equipment to be } \\
\text { included and we are clueless about it. So when that happens sometimes we } \\
\text { will query among ourselves but we couldn't reason it out" }\left(\mathrm{G}_{4} \mathrm{P}_{10}\right) \\
\text { "I feel the reading material did not properly outlined what we supposed to } \\
\text { do and what we should know. The flow is not that clear before we go in" } \\
\left(\mathrm{G}_{6} \mathrm{P}_{19}\right)\end{array}$ \\
\hline
\end{tabular}

Theme 1: Confidence level of EHCW in resuscitating suspected COVID-19 patients

Participants agreed that the COVID-ACLS course has helped build up their confidence in handling resuscitation of a potential COVID-19 patient. They emphasised that this course has enabled them to acquire new knowledge such as aerosolised generating procedure, the COVID-19 virus transmission methods and ways to prevent them. As this is a novel virus with still ongoing research, there are still many things that are unknown to us. With the rising number of patients in the pandemic, EHCW barely have the time to equip themselves with the knowledge to overcome the virus. Hence, by attending this course, the participants have the chance to learn new knowledge.

The participants also expressed relief when they learned of self-precaution from the COVID-ACLS course. 
The course has emphasised that the utmost priority is to protect oneself before rushing to the patient's side. By securing a barrier between EHCWs and high-risk patients, the risk of spreading can also be put down to a minimum. This will then provide a sense of security and boost EHCW's confidence when attending to susceptible patients. Another factor that has contributed to confidence among EHCW is the method of delivery we adopted to instil new knowledge. Simulation training is able to provide a real case-based scenario that mimics common cases presenting to the emergency department. Most of the participants leaned towards kinesthetic learning, especially when it involves simulating a true resuscitation team.

\section{Theme 2: Anxiety of EHCW in a susceptible to COVID-19 environment}

The anxiety among EHCW originates from their concerns toward safety. They have constant fear of bringing back the virus to their loved ones because majority of them live with vulnerable age groups i.e. elderly and young children. Due to the super spreader nature of the virus, the possibility of transmitting the virus is very high. Many took a step further by sanitising themselves before embracing their family members or even underwent COVID-19 testing before going back to their hometown. They also felt stressed when they learned of colleagues who are being quarantined. The vague signs and symptoms of COVID-19 could obscure judgement and lower EHCW suspicion index.

EHCW reported that lacking of PPE resources also heighten their anxiety as they would later insecure and unsafe to work in a high-risk environment. The COVIDACLS currently limit two people for managing airway during resuscitation. However, this posed as a problem when only two medical personnel have to rotate among themselves for CPR and ventilating the patient. Another participant also points out that we should consider the usage of PAPR for EHCW working in resuscitation bay.

Few of the participants expressed concerns regarding stigmatisation as a health care worker. One participant shared regarding his personal experience of being singled out after breeched PPE protocol unintentionally. Another participant observed how an EHCW colleague was treated and blamed for contracting the disease. One participant also shared how she felt uneasy when people stared at her for wearing working scrubs outside the hospital. All these experiences also contributed to the anxiety level while being a frontliner.
Overwhelming workload and being the frontliner fighting against the pandemic resulting in EHCW feeling underappreciated. Being overworked, yet no appreciation was given have contributed to this feeling. Despite that, EHCWs are still bound by their sense of responsibility to present for work and continue providing care for patients.

\section{Theme 3: Area for improvement}

Participants agreed that the COVID-ACLS course is beneficial in handling resuscitation and should be done regularly. Video-assisted learning is suggested as another method of delivery for future COVID-ACLS. They recommended that instead of handing out written materials for reading, video demonstration will be better for visual learner. This will then be easier for participants to pick up new skills and able to reproduce it during simulation training later.

\section{Theme 4: Sufficiency of COVID-ACLS course}

All participants have dubbed the COVID-ACLS being beneficial. However, there are few areas that is still lacking to be deemed as a sufficient course. For instance, COVID-ACLS training is shorter than other life support courses as it only requires 1 to 2 hours. The participants also feedback that there is no assessment to ensure that the participant has learned and able to practice it on daily practice later. The reading material provided to participants before the training has received both praise and critics. For improvement purpose, the participants pointed out that the content is simplified and no detail explanation was provided for each skill set. They also mention that the content in the written guideline is too brief and insufficient.

\section{DISCUSSION}

In our study, we highlighted anxiety factors among EHCW in handling a suspected COVID-19 patient and how it can be overcome by COVID-ACLS training. In order to improve this training, we also gather suggestions and weakness from participants so that it can be adapted to future training. Lastly, we analysed feedback from participants and determine if this training and guideline is sufficient to be adopted into this pandemic era to handle susceptible patients. These areas are categorised into four themes as according to our research questions: Confidence level of EHCW in resuscitating suspected COVID-19 
patients, Anxiety of EHCW, Area for improvement, and sufficiency of COVID-ACLS course.

The emergence of novel coronavirus has swept across countries globally and caused mortality of over 1 million. Since the early phase of pandemic, 152,888 health care workers have been infected, and 1413 deaths reported (Bandyopadhyay et al. 2020). In Malaysia, Health director-general Dr Noor Hisham Abdullah stated that 1880 health care workers tested positive for COVID-19 at the date of writing. This could be due to the fact that a health care worker does not have adequate knowledge of COVID-19. Bhagavathula et al. (2020) identified there is significant knowledge gaps between doctors and other health care workers in a mode of transmission and incubation period of COVID- 19 . Ignorance could lead to EHCW not adhering to protocols in managing high-risk patients, subsequently accelerated the transmission to surrounding people instead. Wang et al. (2020) have supported this in their study, whereby a quarter of $\mathrm{HCW}$ contracted coronavirus from a single patient during the early phase of the outbreak in China. Hence, the new knowledge of AGP should be taught and highlighted to every EHCW. If the EHCW's knowledge and awareness can be heightened, they will be more confident in managing a possible COVID-19 patient.

Another reason that has been identified able to boost up confidence among EHCW is the sense of security and feeling well protected when working in a susceptible environment. The coronavirus is highly contagious and easily transmitted via droplets, especially in AGP such as CPR and intubation during resuscitation. From the focus group interview, participants expressed how important it was for them to learn ways to secure their safety. Schwartz et al. (2020) stated that a rapidly developing epidemic may result $\mathrm{HCW}$ to refuse or be unable to work, resulting to be critical $\mathrm{HCW}$ shortages. This reflects that EHCW needs to feel protected before knowing they can provide care confidently without compromising patient's care. Lam and Hung (2013) study identified that 4 out of 10 participants expressed concerns about their susceptibility to human swine influenza infection. However, with effective training, we can equip our EHCW with the knowledge and clinical skills applicable to patient care, which would benefit their capabilities for handling major health emergency threats (Leiba et al. 2006; Vinson 2007).
All our participants expressed how COVID-ACLS has benefited them; one of the main advantages would be learning via simulation training. In COVID-ACLS training, we have assigned roles to each member and ask them to perform accordingly, re-enacting a real scenario. The majority has given feedback that it helps them grasp the COVID-ACLS content better, which is similar to the current AHA ACLS course. Lee et al. (2010) found that students who underwent scenario-based, performanceoriented team instruction perform better and strongly advocate for this better teaching model. Langdorf et al. (2011) also supported that high-fidelity simulation is more emotionally intense and arguably enhances retention. This reflects that high-fidelity simulation with a more realistic environment can lead to higher satisfaction and long term knowledge retention (Lo et al. 2011).

The number of growing cases has imposed EHCWs in a steep-ascending workload, a high risk of infection towards themselves and their family members. Our study identified that anxiety factors among EHCW mainly revolves around infection of family members, infection of colleagues, and getting infected themselves. Lai et al. (2020) stated that HCW responding to the spread of COVID-19 reported high rates of symptoms of depression, anxiety, insomnia and distress. Tan et al. (2020) also demonstrated that $14.5 \%$ of HCW screened positive for anxiety, $8.9 \%$ for depression, $6.6 \%$ for stress and $7.7 \%$ for clinical concern of post-traumatic stress disorder. These insecurities can weaken EHCWs' confidence and impede health care delivery when they are unable to stay calm. Several studies have suggested that medical workers' perception of overwhelmed responsibility for work, facing uncertainties, short of training and lack of support from superiors are important exogenous factors causing occupational stresses on HCW (Domagała et al. 2018; Du et al. 2020). This is consistent with our finding whereby participants also reported a feeling of underappreciation. A simple, genuine expression of gratitude could reinforce compassion of HCW in this pandemic (Shanafelt et al. 2020). Reinforcing compassion among EHCW can help them overcome empathetic distress and fear to provide care under extraordinarily difficult circumstances every day (Singer \& Klimecki 2014). During the H1N1 outbreak, Japan showed policies that take care of health care and give physicians confidence positively affected the overall care they provide to the population (Imai 2020; Maunder 2009). 
All our participants mentioned that COVID-ACLS should be a continuing training session. The single training was not adequate to instil the knowledge into our daily practice. Since most of our participants have at least five years of working experience in the emergency field, it was not easy to replace the conventional practice with only a one-time training. Furthermore, Malaysia did not have any prior experience in handling respiratory illness epidemics such as SARS, and human swine influenza in such a large scale. Therefore, Abd Samat et al. (2020) and Boonmak et al. (2004) strongly advocated that repeated short courses may help to maintain knowledge and provide an opportunity to learn without endangering patients. In another study by Nambiar et al. (2016) in assessing BLS/ACLS retention knowledge, the mean score was reported to be lower after training plausibly due to lack of regular practice. Hence it is strongly suggested that frequent regular practice should be done among the EHCWs.

Due to shortage of manpower and limited opportunities for more frequent training sessions, one of the suggestions given was to have video teaching. Few of our participants have concocted the idea of recording the training of new skill in video and circulating among all EHCWs. By doing this, EHCWs can refresh their memory by watching the video during their free time to refresh memory. Additionally, this will also benefit visual learner and aid in learning instead of just reading from the written guidelines. Few studies have supported video-assisted CPR learning are as effective as conventional CPR teaching. Beskind et al. (2016) demonstrated that a 60 seconds video and CPR only class to high school student had improved CPR quality, responsiveness and long-term retention of lay-bystander CPR skills. In another study, Beskind et al. (2017) intervened with an ultra-brief video of 30 seconds of CPR teaching as commercial in a basketball game, also reported having improved lay-bystander CPR performance and responsiveness. This shows that video teaching is feasible and can be adapted to COVID-ACLS training later.

The traditional ACLS course requires two days of training but offers refresher course yearly (Lee et al. 2010). In the case of COVID-ACLS, all participants feedback that the course duration is insufficient, which is about 1 to 2 hours only. As mentioned earlier, the majority of our participants have at least five years of working experience in the emergency department. However, the COVID-ACLS training is advocating a novel practice to reduce transmission of droplets and AGP. This is especially difficult for EHCW to retain their knowledge and practice during resuscitation later. Moreover, this can be improvised by providing a video of a new skill for $\mathrm{EHCW}$ to revise during their free time. For future training, this can be considered as it is not feasible to conduct regular training during the pandemic.

Another issue that was critiqued by the participants is the unsatisfactory reading material. A majority felt that the content is not sufficient and rather brief, given that it is a reference guideline. Given the fact that this virus is still new and evolving, it is not practical to publish a new informative guideline whenever there is a new discovery of the virus. By doing so, it may cause confusion to EHCW due to information overload and neglect the essence of the training which is definitive airway management during resuscitating a potential COVID-19 patient. Caley et al. (2010) stated that physicians were overwhelmed by health care advice during the HIS outbreak because excessive information was provided by the health care authority. Another study also supported that ambiguity of the guidelines could adversely affect adherence to infection control measures and consequently increase the risk of hospital-acquired infections to the staff and the public (Elliott 2009).

\section{LIMITATIONS}

Due to the strict protocol of practising physical distancing and self-protection in any event involving group gathering, all of our participants have to adhere to the standard protocol by wearing a face mask. This impeded us by interpreting participants' facial expression during the focused group interview. Despite consented to participate in the group focused interview, many participants felt uneasy knowing that they are being recorded. When participants felt uneasy, they would be prone to provide ideal answers, thus yielding biased results.

\section{CONCLUSION}

In conclusion, the COVID-ACLS training holds a beneficial purpose to all EHCW by building up confidence level in resuscitating a high-risk COVID-19 patient by teaching new knowledge to the participants, especially regarding AGP procedures. EHCW felt more confident after going through simulation training of COVID-ACLS. They also felt more confident handling a 
potential COVID-19 patient knowing that they are wellprotected. The anxiety of EHCW mainly revolves around safety and fear of transmitting the virus to surrounding people, which is alleviated by knowing that they are well-protected through PPE, as propagated by the COVIDACLS. Area of improvements needed for future COVIDACLS include regular training sessions, adopting other teaching modalities such as video learning, inviting other specialties (anaesthesiologist and otorhinolaryngologist) to collaborate in COVID-ACLS and suggesting better equipment (LUCAS and PAPR). The COVID-ACLS is an appropriate course with few limitations, which should be attended to. Brief course duration and unsatisfactory reading materials can be compensated by providing a learning video-lecture in a future training course.

\section{ACKNOWLEDGEMENTS}

We would like to express our gratitude to the Faculty of Medicine, Universiti Kebangsaan Malaysia, for the permission to collect data and approval of this study with the approval code of JEP-2020-481.

\section{REFERENCES}

Abd Samat, S.A., Isa, M.H., Sabardin, D.M., Md Jamal, S., Jaafar, M.J., Hamzah, F.A., Mahmud, A., Sanip, A., Syed Ali, S.M. \& Mohd Saiboon, I. 2020. Knowledge and confidence level among emergency healthcare workers in airway management and resuscitation of suspected COVID-19 patients: A cross sectional study in Malaysia. Ann. Acad. Med. Singap. 49: 643-651.

Bandyopadhyay, S., Baticulon, R.E., Kadhum, M., Alser, M., Ojuka, D.K., Badereddin, Y., Kamath, A., Parepalli, S.A., Brown, G., Iharchane, S., Gandino, S., Markovic-Obiago, Z., Scott, S., Manirambona, E., Machhada, A., Aggarwal, A., Benazaize, L., Ibrahim, M., Kim, D., Tol, I., Taylor, E.H., Knighton, A., Bbaale, D., Jasim, D., Alghoul, H., Reddy, H., Abuelgasim, H., Saini, K., Sigler, A., Abuelgasim, L., Moran-Romero, M., Kumarendran, M., Jamie, N.A., Ali, O., Sudarshan, R., Dean, R., Kissyova, R., Kelzang, S., Roche, S., Ahsan, T., Mohamed, Y., Dube, A.M., Gwini, G.P., Gwokyala, R., Brown, R., Papon, M.R.K.K., Li, Z., Ruzats, S.S., Charuvila, S., Peter, N., Khalidy, K., Moyo, N., Alser, O., Solano, A., Robles-Perez, E., Tariq, A., Gaddah, M., Kolovos, S., Muchemwa, F.C., Saleh, A., Gosman, A., Pinedo-Villanueva, R., Jani, A. \& Khundkar, R. 2020. Infection and mortality of healthcare workers worldwide from COVID-19: A systematic review. BMJ Global Health 5(12): e003097.

Berg, B. 2007. An introduction to content analysis. In Qualitative Research Methods for the Social Sciences, edited by Berg, B.L. Boston: Allyn and Bacon. pp. 238-267.

Beskind, D.L., Stolz, U., Thiede, R., Hoyer, R., Robertson, W., Brown, J., Ludgate, M., Tiutan, T., Shane, R. \& Mcmorrow, D. 2017. Viewing an ultra-brief chest compression only video improves some measures of bystander CPR performance and responsiveness at a mass gathering event. Resuscitation 118: 96-100.

Beskind, D.L., Stolz, U., Thiede, R., Hoyer, R., Burns, W., Brown, J., Ludgate, M., Tiutan, T., Shane, R. \& Mcmorrow, D. 2016. Viewing a brief chest-compression-only CPR video improves bystander CPR performance and responsiveness in high school students: A cluster randomised trial. Resuscitation 104: 28-33.

Bhagavathula, A.S., Aldhaleei, W.A., Rahmani, J., Mahabadi, M.A. \& Bandari, D.K. 2020. Novel Coronavirus (COVID-19) Knowledge and Perceptions: A Survey on Healthcare Workers. MedRxiv. doi.org/10.1101/2020.03.09.20033381.

Boonmak, P., Boonmak, S., Srichaipanha, S. \& Poomsawat, S. 2004. Knowledge and skill after brief ACLS training. $J$. Med. Assoc. Thai 87(87): 1311-1314.

Caley, M., Sidhu, K. \& Shukla, R. 2010. GPS' Opinions on the NHS and HPA response to the first wave of the influenza a/ H1n1v pandemic. Br. J. Gen. Pract. 60(573): 283-285.

Denzin, N.K. \& Lincoln, Y.S. 2008. Strategies of Qualitative Inquiry. 3rd ed. Thousand Oaks, CA: Sage.

Domagała, A., Bała, M.M., Storman, D., Peña-Sánchez, J.N., Świerz, M.J., Kaczmarczyk, M. \& Storman, M. 2018. Factors Associated with satisfaction of hospital physicians: A systematic review on European data. International Journal of Environmental Research and Public Health 15(11): 2546.

Du, J., Dong, L., Wang, T., Yuan, C., Fu, R., Zhang, L., Liu, B., Zhang, M., Yin, Y. \& Qin, J. 2020. Psychological symptoms among frontline healthcare workers during COVID-19 outbreak in Wuhan. General Hospital Psychiatry 67: 144145.

Elliott, P. 2009. Infection Control: A Psychosocial Approach to Changing Practice. London: Radcliffe Publishing.

Imai, H. 2020. Trust is a key factor in the willingness of health professionals to work during the COVID-19 outbreak: Experience from the H1N1 pandemic in Japan 2009. Psychiatry and Clinical Neurosciences 74(5): 329-330.

Lai, J., Ma, S., Wang, Y., Cai, Z., Hu, J., Wei, N., Wu, J., Du, H., Chen, T. \& Li, R. 2020. Factors associated with mental health outcomes among health care workers exposed to coronavirus disease 2019. JAMA Network Open 3(3): e203976-e203976.

Lam, K.K. \& Hung, S.Y.M. 2013. Perceptions of emergency nurses during the human swine influenza outbreak: A qualitative study. International Emergency Nursing 21(4): 240-246.

Langdorf, M.I., Strom, S.L., Yang, L., Canales, C., Anderson, C.L., Amin, A. \& Lotfipour, S. 2014. High-fidelity 
simulation enhances ACLS training. Teaching and Learning in Medicine 26(3): 266-273.

Lee, C.C., Im, M., Kim, T.M., Stapleton, E.R., Kim, K., Suh, G.J., Singer, A.J. \& Henry, M.C. 2010. Comparison of traditional advanced cardiac life support (ACLS) course instruction vs. a scenario-based, performance oriented team instruction (SPOTI) method for Korean paramedic students. The Journal of Emergency Medicine 38(1): 89-92.

Leiba, A., Goldberg, A., Hourvitz, A., Amsalem, Y., Aran, A., Weiss, G., Leiba, R., Yehezkelli, Y., Goldberg, A. \& Levi, Y. 2006. Lessons learned from clinical anthrax drills: Evaluation of knowledge and preparedness for a bioterrorist threat in Israeli emergency departments. Annals of Emergency Medicine 48(2): 194-199.

Li, Z., Ge, J., Yang, M., Feng, J., Qiao, M., Jiang, R., Bi, J., Zhan, G., Xu, X., Wang, L. \& Zhou, Q. 2020. Vicarious traumatisation in the general public, members, and nonmembers of medical teams aiding in COVID-19 control. Brain, Behavior, and Immunity 88: 916-919.

Lincoln, Y.S. 2007. Naturalistic inquiry. In The Encyclopedia of Sociology, edited by Ritzer, G. Vols. 1-6. Oxford, England: Blackwell Publishing Co.

Lo, B.M., Devine, A.S., Evans, D.P., Byars, D.V., Lamm, O.Y., Lee, R.J., Lowe, S.M. \& Walker, L.L. 2011. Comparison of traditional versus high-fidelity simulation in the retention of ACLS knowledge. Resuscitation 82(11): 1440-1443.

Maunder, R.G. 2009. Was SARS a mental health catastrophe? General Hospital Psychiatry 31(4): 316.

Merriam, S.B. \& Tisdell, E.J. 2015. Qualitative Research: A Guide to Design and Implementation. New York: John Wiley \& Sons.

Nambiar, M., Nedungalaparambil, N.M. \& Aslesh, O.P. 2016. Is current training in basic and advanced cardiac life support (BLS \& ACLS) effective? A study of BLS \& ACLS knowledge amongst healthcare professionals of NorthKerala. World Journal of Emergency Medicine 7(4): 263.

Patton, M.Q. 2002. Two decades of developments in qualitative inquiry: A personal, experiential perspective. Qualitative Social Work 1(3): 261-283.

Schwartz, J., King, C.C. \& Yen, M.Y. 2020. Protecting health care workers during the COVID-19 coronavirus outbreak- lessons from Taiwan's SARS response. Clin. Infect. Dis. 71(15): 858-860.

Shanafelt, T., Ripp, J. \& Trockel, M. 2020. Understanding and addressing sources of anxiety among health care professionals during the COVID-19 pandemic. JAMA 323(21): 2133-2134

Singer, T. \& Klimecki, O.M. 2014. Empathy and compassion. Current Biology 24(18): R875-R878.

Tan, B.Y.Q., Chew, N.W.S., Lee, G.K.H., Jing, M., Goh, Y., Yeo, L.L.L., Zhang, K., Chin, H.K., Ahmad, A., Khan, F.A., Shanmugam, G.N., Chan, B.P.L., Sunny, S., Chandra, B., Ong, J.J.Y., Paliwal, P.R., Wong, L.Y.H., Sagayanathan, R., Chen, J.T., Ying Ng, A.Y., Teoh, H.L., Ho, C.S., Ho, R.C. \& Sharma, V.K. 2020. Psychological impact of the COVID-19 pandemic on health care workers in Singapore. Annals of Internal Medicine M20-1083.

Vinson, E. 2007. Managing Bioterrorism mass casualties in an emergency department: Lessons learned from a rural community hospital disaster drill. Disaster Management \& Response 5(1): 18-21.

Wang, J., Zhou, M. \& Liu, F. 2020. Reasons for healthcare workers becoming infected with novel coronavirus disease 2019 (COVID-19) in China. J. Hosp. Infect. 205: 100-101.

Wu, D., Wu, T., Liu, Q. \& Yang, Z. 2020. The SARS-CoV-2 outbreak: What we know. International Journal of Infectious Diseases 94: 44-48.

Wu, Z. \& Mcgoogan, J.M. 2020. Characteristics of and important lessons from the coronavirus disease 2019 (COVID-19) outbreak in China: Summary of a report of 72314 cases from the Chinese center for disease control and prevention. JAMA 323(13): 1239-1242.

Faculty of Medicine

Universiti Kebangsaan Malaysia

Jalan Yaacob Latif, Bandar Tun Razak

56000 Cheras, Kuala Lumpur, Federal Territory

Malaysia

*Corresponding author; email: alias6972@gmail.com

Received: 31 January 2021

Accepted: 20 July 2021 